\title{
The Influence of Service Quality and Customer Satisfaction of the BRImo Application on Customer Loyalty
}

\author{
Agus Riyan Saputra \\ Sriwijaya University, Palembang, Indonesia \\ Corresponding author email: agusriyansaputra19@gmail.com
}

Zakaria Wahab

Sriwijaya University, Palembang, Indonesia

Email: zkwahab01@gmail.com

\section{Muchsin Saggaf Shihab}

Sriwijaya University, Palembang, Indonesia

Email: muchsin.shihab@bakrie.ac.id

\author{
Marlina Widiyanti \\ Sriwijaya University, Palembang, Indonesia \\ Email: marlinawidiyanti68@yahoo.co.id
}

\begin{abstract}
This study was conducted to determine service quality and customer satisfaction on the BRImo application on customer loyalty at PT Bank Rakyat Indonesia (Persero), Tbk Sekayu branch office. The population in this study were all customers at PT. Bank Rakyat Indonesia (Persero), Tbk Sekayu Branch Office, as many as 850 customers in the Kl customer category, which focuses on BRImo users in 2020-2021. The sample used in this study was 123 respondents with purposive sampling techniques. The multiple linear regression analysis results show that service quality has a positive and significant effect on customer loyalty. Customer satisfaction has a positive and significant effect on customer loyalty. The results of this study are expected. PT Bank Rakyat Indonesia (Persero), Tbk can improve the application network regularly and provide additional employees in the IT department so that customers can always use the BRImo application at any time. In addition, the increase in the appearance and needs of customers in the BRImo application service can be further improved so that customers can be more efficient in conducting transactions using only smartphones without the need to come directly to the BRI bank.
\end{abstract}

Keywords---application network, application service, customer loyalty, customer satisfaction, service quality.

\section{Introduction}

Customer loyalty is essential for PT Bank Rakyat Indonesia (Persero), Tbk because customers are the most valuable asset for the sustainability and existence of a company (Lin \& Wang, 2006). Customer loyalty has a powerful influence on profits, especially customer loyalty resulting from the excellent relationship between the company and its customers (Amin et al., 2012; Chadhiq \& Yusroni, 2021). Customer loyalty is a multidimensional concept which is a type of customer preference for products and services that has been formed for a long time related to the cognitive, affective, and conative aspects of consumer behavior (Oliver, 1999). Loyal consumers remain committed to making purchases at the same brand, are willing to pay a higher price for a product or service brand, and continuously promote the brand (Natarajan et al., 2016).

The bank is a financial institution that is authorized and functions in collecting public funds and then distributing them to the public. Furthermore, according to State Law No. 10 of 1998, it is explained that the bank is a business 
entity in which the implementation collects funds from the community in the form of a deposit and then distributes it to the public either in the form of credit or other forms to improve the standard of living of the people. So from the current understanding and explanation, it is concluded that the bank is one of the institutions that collect funds from the public in the form of deposits/savings, demand deposits, or deposits where funds are distributed to people in need, both in credit and loan products. other product forms (www.ojk.go.id).

Mobile banking is one of the innovations developed to carry out banking financial transactions through smartphones starting from balance checks, fund transfers, bill payments, information, and other banking services that can be accessed anytime and anywhere (Ensor, 2012). These services have great opportunities for banks to provide added value for their users. The Mobile Banking product's marketing can have direct implications for technology adoption. Mobile banking can be interpreted as a banking service that was created to support the convenience and smoothness of customers in carrying out banking activities so that an effective and efficient value emerges in carrying out transaction activities in the banking sector. This certainly will not be optimal if media tools do not support it in optimizing mobile banking activities.

The number of internet users in Indonesia in the second quarter of 2020 has reached 196.7 million people, with a percentage reaching $73.7 \%$. When compared to 2018, the number of internet users in Indonesia was only around $64.8 \%$, with a total of 171.2 million people (www.kompas.com, 2021). PT. Bank Rakyat Indonesia (Persero), Tbk, which is a state-owned bank, has presented a banking service application in the form of BRI Mobile, which has been released especially for its customers since around 2010, where this application was created not only for dealing with banking but also for synergies and collaboration. Technology with other cellular operators.

On February 27, 2019, Mrs. Handayani, as one of the Consumer Directors of Bank BRI, officially released the latest version of the digital banking application from BRI Mobile, namely the BRImo application (launched on the detik.com website). It should be noted that BRImo is a new application owned by Bank BRI to combine several functions of mobile banking, internet banking, and electronic money (LinkAja) into one application that is much more complete and attractive. One of the conveniences that can be accessed is filling out and paying credit, paying train tickets, paying for credit cards, top-up GoPay balances. Of course, customers can get information and promos owned by Bank BRI without having to come directly to the BRI Branch Office. The following is the growth in the use of the BRImo application at PT. Bank Rakyat Indonesia (Persero), Tbk.

Based on the data in Figure 1.1 above, it can be seen that the use of the BRImo application in the last five years, namely 2015 to 2019, has increased continuously. Furthermore, Hari Purnomo as the corporate secretary of Bank BRI, which was covered on liputa6.com, explained that the average increase in BRImo users each month reached 250 thousand to 350 thousand users. The increasing use of the application shows a change in people's habits, especially customers from Bank BRI itself; customers are more enthusiastic about transacting through digital banking than transacting directly to existing Branch Offices.

In 2021, the number of digital transactions through Bank BRI's e-channels will reach 5.7 billion transactions. Meanwhile, in terms of volume, Bank BRI was able to record IDR 4,617 trillion, an increase of 57\% compared to the same period in 2020, even when compared to the pre-pandemic period, there was an increase of $68 \%$ (YoY June 2019 - June 2021). One of BRI's leading e-channels, BRImo, contributes $25 \%$ or 1.165 trillion Rupiah and this is evidenced by the trend that continues to increase every year by 169\% (YoY June 2019 - June 2021) and 94\% (YoY June 2020 - June 2021) (www.bri.co.id, 2021).

This achievement is supported by continuous innovation in the BRImo application. Where based on the results of the SLE (Satisfaction, Loyalty, and Engagement) survey in the 2021 version of Infobank and Marketing Research Indonesia (MRI), BRImo became the best mobile banking service, and BRI bank received an award as a bank with mobile banking quality at the 2021 SLE award event. Bromo quality makes BRI Bank have the best mobile banking, where BRImo is an application that can answer all the financial and banking transaction needs of customers (reported by Infobanknews.com).

BRI bank indeed prioritizes service quality and customer satisfaction by launching a service product (Gustafsson, 2009). Wherewith the current offers on the BRImo application, it is found that there are a few problems that are felt by customers who use the BRImo application service (Jang \& Namkung, 2009; Hong et al., 2011). One of these problems is such as the lack of customer trust to use BRImo services, the accuracy of the BRImo service itself, the dependence of BRmo services with cellular operators, which is related to the speed performance of service transactions, and lastly, the most significant security risk in the form of non-encrypted providers cell phone service. This can be a gap for hackers to obtain account information and credit card information from users, especially if the mobile phone of the BRImo application user is lost or even stolen so that the information contained in a message can be easily used later by other parties. 
PT Bank Rakyat Indonesia (Persero), Tbk Sekayu Branch office, which is part of the BRI Palembang regional office. The office is located on Jl. Lieutenant Munandar no. 397 Balai Agung Village, Sekayu District, Musi Banyuasin Regency, where the working area of BRI's Sekayu Branch Office covers Musi Banyuasin and Banyuasin Regencies, overseeing 2 Sub-Branch Offices and 13 Work Units spread across the two regencies. Currently, the number of BRImo users at BRI's Sekayu Branch Office for 2020-2021 has reached 850 users, where later, the sample used for the study will be 123 customers as samples.

\section{Research Methods}

The population in this study were all customers at PT. Bank Rakyat Indonesia (Persero), Tbk Sekayu Branch Office, as many as 850 customers in the K1 customer category, which focuses on BRImo users in 2020-2021. Based on the sample calculation above, the sample to be used in this study is 123,311 , which is rounded up to $123 \mathrm{~K} 1$ customers who focus on BRImo users in the period 2020-2021 at PT. Bank Rakyat Indonesia (Persero), Tbk. The sampling technique in this study used a purposive sampling technique. The criteria for respondents who were taken as samples were K1 customers or BRImo users in 2020-2021 at PT. Bank Rakyat Indonesia (Persero), Tbk. Furthermore, respondents will be contacted by telephone or direct visits by distributing questionnaires or via a google form.

\section{Results and Discussion}

Individual Parameter Significance Test Results ( $t$-Test)

a) The service quality variable (X1) has a beta value of 0.186 with a significant value of 0.003 , more diminutive than 0.05 . This shows that the service quality variable positively influences customer loyalty at PT Bank Rakyat Indonesia (Persero), Tbk. This proves that the first hypothesis on the service quality variable has a positive and significant effect and can be accepted.

b) The customer satisfaction variable (X2) has a beta of 0.688 with a significance value of 0.000 , more diminutive than 0.05 . This shows that the variable customer satisfaction has a positive and significant influence on customer loyalty at PT Bank Rakyat Indonesia (Persero), Tbk. This proves that the second hypothesis on the variable customer satisfaction has a positive and significant effect and can be accepted.

Service quality has a positive and significant effect on customer loyalty. These results are in line with research results from (Fida et al., 2020), (Jeany \& Siagian, 2020), (Nguyen et al., 2020), (Saputra, 2020), (Alauddin et al., 2019), (Nuraina \& Arafah, 2020), (Susanto \& Subagja, 2019), (Cuong \& Khoi, 2019), (Joudeh \& Dandis, 2018), (Almassawa, 2018), (Punsala \& Abeysekera, 2020), (Adnyana \& Suprapti, 2018), (Zildiz, 2017), (Ishak \& Azzahroh, 2017), (Hadiwidjaja, 2017), (Puriwat \& Tripopsakul, 2017), (Aziz, 2017), (Chen \& Liu, 2017), show the results that service quality has a positive and significant effect on customer loyalty.

The results of this study indicate that service quality is associated with several indicators such as efficiency (efficiency), fulfillment of needs (fulfillment), system availability (system availability), privacy (privacy), responsiveness (responsiveness) (Kamal \& Azizah, 2021). The BRImo application indicator does not crash frequently, showing the lowest value. It is suspected that the BRImo application still often encounters problems when used by customers (Brady \& Robertson, 2001; Yoon \& Suh, 2003). Based on direct interviews with customers as respondents in this study, customers complained about the BRImo application, which sometimes could not be used. The indicator that BRImo can meet the needs of customers' mobile transactions shows the highest score. This shows that the BRImo application has been able to meet the needs of mobile transactions for customers. With the development of technology with the BRImo application, it is easier for customers to make transactions more effectively and efficiently just by using a smartphone.

Customer satisfaction has a positive and significant effect on customer loyalty (Cossío-Silva et al., 2016). These results are in line with research results from (Fida et al., 2020), (Jeany \& Siagian, 2020), (Nguyen et al., 2020), (Saputra, 2020), (Alauddin et al., 2019), (Nuraina \& Arafah, 2020), (Susanto \& Subagja, 2019), (Cuong \& Khoi, 2019), (Joudeh \& Dandis, 2018), (Musqari \& Huda, 2018), (Punsala \& Abeysekera, 2020), (Adnyana \& Suprapti, 2018), (Warsito, 2018), (Zildiz, 2017), (Ishak \& Azzahroh, 2017), (Puriwat \& Tripopsakul, 2017), (Ardiana \& Arianti, 2016), (Welim \& Arifin, 2016), show the results that customer satisfaction has a positive and significant effect on customer loyalty.

The results of this study indicate that customer satisfaction is associated with several indicators such as general or overall satisfaction (overall satisfaction), confirmation of expectations (confirmation of expectations), comparison with ideal situations (comparison to ideal). The BRImo application indicator has never had a problem showing the lowest value. It is suspected that customers still feel obstacles in using the BRImo application. Several customers in 
this study said that crashes on the BRImo application often occur. We are satisfied with the application's ease of use, which shows the highest score. This shows that customers are satisfied with using the BRImo application, which is easy to understand. The interface of the BRImo application, which is easy to understand for all people to use, is made with an easy interface to use (Matzler et al., 2004; Mihelis et al., 2001).

\section{Conclusions}

Service quality and customer satisfaction of the BRImo application have a positive and significant effect on customer loyalty at PT Bank Rakyat Indonesia (Persero), Tbk Sekayu branch office.

\section{Acknowledgments}

Service quality and customer satisfaction of the BRImo application have a positive and significant effect on customer loyalty at PT Bank Rakyat Indonesia (Persero), Tbk Sekayu branch office.

\section{References}

Adnyana, D. G. A., \& Suprapti, N. W. S. (2018). Pengaruh kualitas pelayanan dan persepsi harga terhadap kepuasan dan loyalitas pelanggan gojek di kota denpasar. E-Jurnal Manajemen Universitas Udayana, 7(p11), 6041.

Alauddin, M., Ahsan, S. H., Mowla, M. M., Islam, M. M., \& Hossain, M. M. (2019). Investigating the relationship between service quality, customer satisfaction and customer loyalty in hotel industry: Bangladesh perspective. Global Journal of Management and Business Research, 19(1), 1-8.

Almassawa, S. F. (2018). Pengaruh kualitas pelayanan, citra perusahaan dan implikasi kepuasan pelanggan terhadap loyalitas pelanggan. KREATIF: Jurnal Ilmiah Prodi Manajemen Universitas Pamulang, 6(3), 69-84.

Amin, S. M., Ahmad, U. N. U., \& Hui, L. S. (2012). Factors contributing to customer loyalty towards telecommunication service provider. Procedia-Social and Behavioral Sciences, 40, 282-286. https://doi.org/10.1016/j.sbspro.2012.03.192

Ardiana, R., \& Arianti, M. (2016). Pengaruh Kualitas Pelayanan Terhadap Kepuasan Pelanggan dan Dampaknya Terhadap Loyalitas Pelanggan Speedy di Kota Cimahi. Jurnal Manajemen Bisnis Telekomunikasi \& Informatika.

Aziz, E. K. (2017). Pengaruh Kualitas Pelayanan terhadap Loyalitas Nasabah Tabungan BSM: Studi Kasus pada Bank Syariah Mandiri KC. XXX Kota Malang. Iqtishodia: Jurnal Ekonomi Syariah, 2(2), 64-81.

Brady, M. K., \& Robertson, C. J. (2001). Searching for a consensus on the antecedent role of service quality and satisfaction: an exploratory cross-national study. Journal of Business research,51(1), 53-60. https://doi.org/10.1016/S0148-2963(99)00041-7

Chadhiq, U., \& Yusroni, N. (2021). Building a company's positional advantage based on CRM capabilities and marketing intelligence towards marketing performance. International Journal of Business, Economics \& Management, 4(3), 469-476. https://doi.org/10.31295/ijbem.v4n3.1765

Chen, C. M., \& Liu, H. M. (2017). Exploring the impact of airlines service quality on customer loyalty: Evidence from Taiwan. International Journal of Business and Management, 12(5), 36-50.

Cossío-Silva, F. J., Revilla-Camacho, M. Á., Vega-Vázquez, M., \& Palacios-Florencio, B. (2016). Value co-creation and customer loyalty. Journal of Business Research, 69(5), 1621-1625. https://doi.org/10.1016/j.jbusres.2015.10.028

Cuong, D. T., \& Khoi, B. H. (2019). The Relationship between Service Quality, Satisfaction, Trust and Customer Loyalty A Study of Convenience Stores in Vietnam. Journal of Advanced Research in Dynamic and Control Systems, 11, 327-333.

Ensor, S. (2012). Spinster Ecology: Rachel Carson, Sarah Orne Jewett, and Nonreproductive Futurity. American Literature, 84(2), 409-435.

Fida, B. A., Ahmed, U., Al-Balushi, Y., \& Singh, D. (2020). Impact of service quality on customer loyalty and customer satisfaction in islamic banks in the Sultanate of Oman. Sage Open, 10(2), 2158244020919517.

Gustafsson, A. (2009). Customer satisfaction with service recovery. Journal of business research, 62(11), 12201222. https://doi.org/10.1016/j.jbusres.2008.11.001

Hadiwidjaja, R. D. (2017). Analisis Pengaruh Kualitas Pelayanan terhadap Loyalitas Nasabah Baitul Maal wat Tamwil. Jurnal Ilmu Akuntansi, 10(2), 2461-1990.

Hong, I. H., Dang, J. F., Tsai, Y. H., Liu, C. S., Lee, W. T., Wang, M. L., \& Chen, P. C. (2011). An RFID application in the food supply chain: A case study of convenience stores in Taiwan. Journal of food engineering, 106(2), 119-126. https://doi.org/10.1016/j.jfoodeng.2011.04.014 
Ishak, M. Z., \& Azzahroh, E. P. (2017). Pengaruh Kualitas Layanan Terhadap Loyalitas Nasabah Bank Syariah Dengan Kepuasan Nasabah Sebagai Variabel Intervening. JEBIS (Jurnal Ekonomi dan Bisnis Islam)| Journal Of Islamic Economics And Business, 3(1), 26-38.

Jang, S. S., \& Namkung, Y. (2009). Perceived quality, emotions, and behavioral intentions: Application of an extended Mehrabian-Russell model to restaurants. Journal of Business Research,62(4), 451-460. https://doi.org/10.1016/j.jbusres.2008.01.038

Jeany, J., \& Siagian, M. S. (2020). Pengaruh Kualitas Pelayanan Dan Kepuasan Nasabah Terhadap Loyalitas Nasabah Pada Bpr Artha Prima Perkasa. JMBI UNSRAT (Jurnal Ilmiah Manajemen Bisnis dan Inovasi Universitas Sam Ratulangi)., 7(2).

Joudeh, J. M., \& Dandis, A. (2018). Service quality, customer satisfaction and loyalty in an internet service providers. International Journal of Business and Management, 13(8), 108-120.

Kamal, I., \& Azizah, A. N. (2021). The comparison analysis of national health insurance participant's satisfaction level in primary clinics and community health centers in the effort to improve the healthcare service quality. International Journal of Business, Economics \& Management, 4(2), 442-448. https://doi.org/10.31295/ijbem.v4n2.1732

Lin, H. H., \& Wang, Y. S. (2006). An examination of the determinants of customer loyalty in mobile commerce contexts. Information \& management, 43(3), 271-282. https://doi.org/10.1016/j.im.2005.08.001

Matzler, K., Bailom, F., Hinterhuber, H. H., Renzl, B., \& Pichler, J. (2004). The asymmetric relationship between attribute-level performance and overall customer satisfaction: a reconsideration of the importance-performance analysis. Industrial marketing management, 33(4), 271-277. https://doi.org/10.1016/S0019-8501(03)00055-5

Mihelis, G., Grigoroudis, E., Siskos, Y., Politis, Y., \& Malandrakis, Y. (2001). Customer satisfaction measurement in the p https://doi.org/10.1016/S0377-2217(00)00036-9

Musqari, N., \& Huda, N. (2018). Pengaruh Kualitas Layanan terhadap Loyalitas Melalui Variabel Kepuasan pada Lembaga Amil Zakat (Studi pada Baituzzakah Pertamina Kantor Pusat). Perisai: Islamic Banking and Finance Journal, 2(1), 34-53.

Natarajan, S., Kailath, B. J., Kumar, D., \& Kumar, R. (2016). Accelerating occupancy grid map computation with gpu for real-time obstacle detection. In 2016 22nd Annual International Conference on Advanced Computing and Communication (ADCOM) (pp. 38-43). IEEE.

Nguyen, D. T., Pham, V. T., Tran, D. M., \& Pham, D. B. T. (2020). Impact of service quality, customer satisfaction and switching costs on customer loyalty. The Journal of Asian Finance, Economics, and Business, 7(8), 395-405.

Nuraina, N., \& Arafah, S. (2020). Pengaruh Kualitas Pelayanan Terhadap Loyalitas Nasabah Dan Kepuasan Nasabah Pada PT. Bank Syariah Mandiri KCP Medan Marelan Raya. Jurnal Mahasiswa Fakultas Ekonomi dan Bisnis, 1(1), 81-90.

Oliver, R. L. (1999). Whence consumer loyalty?. Journal of marketing, 63(4_suppl1), 33-44.

Punsala, A. A. D. D., \& Abeysekera, R. (2020). The Impact of Service Quality on Customer Loyalty in Sri Lankan Banking Sector with The Mediation Role of Customer Satisfaction.

Puriwat, W., \& Tripopsakul, S. (2017). The impact of e-service quality on customer satisfaction and loyalty in mobile banking usage: Case study of Thailand. Polish Journal of Management Studies, 15.

Saputra, G. (2020). Kualitas Pelayanan Kredit, Kepuasan Nasabah dan Loyalitas Nasabah Studi pada PT. Bank Mandiri Tbk. Jurnal Wacana Ekonomi, 19(1), 034-045.

Susanto, P. H., \& Subagja, I. K. (2019). Pengaruh Kualitas Layanan, Kepuasan Nasabah Dan Citra Perusahaan Terhadap Loyalitas Nasabah Pt. BANK CENTRAL ASIA Tbk Kantor Cabang Pondok Gede Plaza. Jurnal Manajemen Bisnis Krisnadwipayana, 7(1), 69-84.

Warsito, W. S. (2018). Pengaruh Kepuasan Terhadap Loyalitas Nasabah Pada Pt. Bprks Cabang Dago Bandung. Widya Cipta: Jurnal Sekretari dan Manajemen, 2(2), 225-232.

Welim, Y. Y., \& Arifin, A. (2016). Pengaruh Kualitas Layanan Dan Kepercayaan Terhadap Kepuasan Nasabah Dan Dampaknya Pada Loyalitas Nasabah. SENTIA 2016, 8(2).

Yildiz, E. (2017). Effects of service quality on customer satisfaction, trust, customer loyalty and word of mouth: an application on cargo companies in gümüşhane. Global Journal of Economics and Business Studies, 6(12), 81-88.

Yoon, M. H., \& Suh, J. (2003). Organizational citizenship behaviors and service quality as external effectiveness of contact employees. Journal of business research, 56(8), 597-611. https://doi.org/10.1016/S0148-2963(01)002909 